\title{
OPERATION OVERLORD - A SYNOPSIS OF THE D-DAY LANDINGS
}

\author{
Noëlle Cowling \\ Documentation Service, SANDF
}

Arguably the most famous date of the Second World War is the 6th June 1944, better known as D-Day, the date on which the Allies returned to the continent of Europe in Operation Overlord, the greatest amphibious assault ever mounted in the history of warfare. In the first two hours alone 156000 Allied troops went ashore, forming the vanguard for the army of over two million men that was to follow. Although the officers who planned the invasion predicted that the Allies would suffer a tremendously high casualty rate, the inescapable fact was that in order to come to grips with the German Army and destroy it, sooner or later it would be necessary to invade the mainland of Europe. The enthusiasm with which this concept was embraced usually varied in proportion to the distance of the individual from the potential invasion coast.

Both the Allies and Germany had long been preparing for the invasion of France. In November 1943 Field Marshall Erwin Rommel, who was in charge of Germany's efforts to forestall such an incursion, was personally directed by Hitler to carry out an inspection of the French coastline and start setting up obstacles to guard against a seaborne attack. By December Rommel felt acquainted enough with the area to inform Adolf Hitler that he expected the invasion would probably take place in the Pas de Calais area as this offered the Allies the shortest sea route and consequently the easiest access to French ports which they would need to keep their supply line functioning effectively. By the time the Spring of 1944 had arrived, the German army had laid some 6000 000 mines and installed around 517000 foreshore obstacles designed to wreck ships and landing craft.

The German belief that Pas de Calais was the target was encouraged on the part of the Allies by means of an elaborate deception plan codenamed Operation Fortitude. The British had broken the German enigma encoding system which meant that they were able to deceive German intelligence quite completely. This they did by first planting false information in enemy intelligence circles through a system of double agents. As far as D-Day is con- cerned the main ruse which was put into play was that a 1st U.S. Army Group under General Patton was assembled in South East England and ready to invade across the narrowest part of the channel. The Allies were able to determine the success of their efforts by intercepting and decoding German signals, including those between Rommel and Hitler and judging by their reactions it had been a complete success. This put Generals Eisenhower and Montgomery in the fortunate and enviable position of being able to launch the assault in an area and at a time when they knew the enemy was least expecting it.

However, by this stage Rommel and Hitler were becoming increasingly concerned that all their preparations could prove fruitless if the invasion was made through Normandy or Brittany. This possibility suddenly began to appear to be all the more realistic to the German commanders by virtue of the fact that the great port of Cherbourg might constitute the Allied objective although Rommel still felt that the rocky coastline here would hamper landings. Nevertheless the German forces in these two provinces slowly began installing defences. It was in this respect that Rommel experienced one of his primary difficulties - the fact that he was not actually in command of the region which he was supposed to be defending. Instead he was still subordinate to the 68 year old Field Marshall von Rundstedt, who although a respected general and an able and cunning strategist, had given up all hope of defeating an Allied invasion. This attitude had the unfortunate effect of dampening the enthusiasm with which Rommel's plans for defence were carried out. Given these circumstances, and knowing how ineffective his defences really were against a determined invasion, Erwin Rommel knew that his only hope of success was to defeat the invaders on the beaches on D-Day itself.

The Supreme Allied Commander for Overlord, General Dwight D. Eisenhower had nearly 3 000000 men and a massive quantity of equipment, much of which had been specially designed, under his control. Although all of this 
meant that the Allies had a crushing superiority in fighting aircraft and warships, they also had to contend with the natural advantages of defence as well as a shortage of amphibious landing craft. Once in France they faced 43 German divisions which were concentrated in North Western Europe. To achieve success in Normandy therefore, the Allies needed both an element of surprise and air superiority. The former was achieved through Fortitude and the launch of the attack during a spell of appallingly bad weather, something Rommel had thought would be most unlikely. The latter was happily taken care of by Hitler himself who had imposed restrictions on Luftwaffe sorties, due to a chronic fuel shortage.

Later on that same day the German Navy declared that the seas were too rough for the patrol vessels to put to sea. And so it was that the Allied invasion fleet, numbering nearly 6500 vessels, crossed the channel unopposed and began to disgorge their troops at those very places along the French coast which the enemy had least suspected - the Normandy beaches. The beach obstacles had little effect and in the most part were destroyed by sappers landing in advance of the invaders. Special Forces teams were dropped into France before D-Day to rendezvous with the French Resistance and carry out reconnaissance tasks. These combined teams later operated behind German lines, causing havoc to the enemy by blowing up bridges, roads and railways and cutting telephone lines. At 00h20 on 5 June, three American and British paratroop Divisions landed in Normandy to block bridges and destroy the German Lines of Communications so that reinforcements could not easily reach the German front.

The rest of the Allied forces were due to arrive in amphibious landing craft along five Normandy beaches codenamed Utah, Omaha, Gold, Sword and Juno. The Americans came ashore at the first two beaches while the British and Canadians took the remaining three eastern ones. At

about $03 \mathrm{~h} 00$, as the paratroopers began securing their objectives inland, the first Allied warships began to arrive off the Normandy coast. The Air Forces then joined these ships in a preliminary bombardment of the German positions.
Neither Rommel nor Hitler, who were both in Bavaria at the time of the invasion, were informed of the Allied arrival until after $10 \mathrm{~h} 00$ that morning. Rommel only reached Normandy later that night with strict instructions from Hitler to drive the Allies back into the sea before midnight. Although hard fighting on each of the three beaches chosen for the British and Canadian forces ensued they made steady progress inland with the aid of specially designed armoured vehicles. The easiest landings occurred on Utah beach where navigational errors concentrated the landings in areas which happened to be lightly defended. The other American beach - Omaha - was in complete contrast. Here only two of the original 32 landing craft made it to the beach. The rest ran

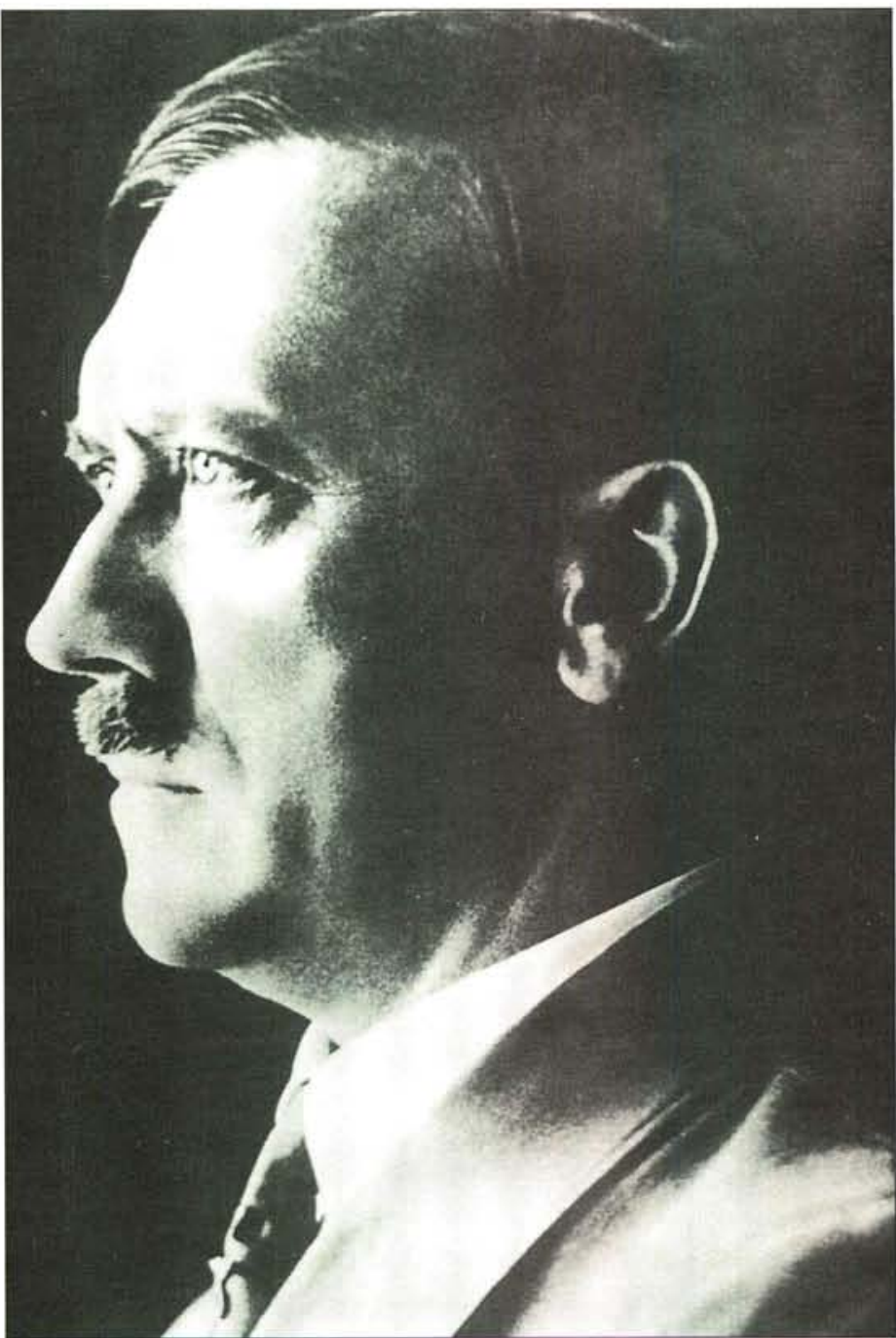

Adolf Hitler was convinced that the Normandy invasion was a decoy and consequently refused to commit more troops to battle in the area.

aground after hitting underwater obstacles. The small force that did make it was confronted by the German 352 Division, an unexpected surprise. America lost 2500 troops at Omaha before nightfall. The British and the Canadians fared somewhat better although 1 
SAS Commando Brigade failed to attain the primary and most ambitious objective of the day - the capture of Caen, to prevent the Germans using it as a strongpoint. They did, however, stop the crucial German armour attack that was intended to drive their forces back into the ocean from whence they had come.

Although the success of Overlord was somewhat diluted by these developments the intelligence provided by Ultra at Bletchley Park was able to tip the balance in the Allies favour. General Montgomery who was now commanding the Allied forces in France was assured that Hitler and his generals were quite convinced that the D-Day landings were a diversionary attack and that the main attack was to be launched further along the coast. As a result Hitler refused to commit any of the reserve and armoured divisions in the area to Rom-mel's command. The Allies therefore faced a force that grew weaker by the day. The German commanders now became convinced that the success of the operations lay in the capture of Cherbourg - a port for landing supplies and reinforcements. The ingenious Allies, however, had planned against the possibility of a failure to take the city by building prefabricated harbours, known as "Mulberries" which they simply then towed across the Channel. Allied progress was consequently never impeded by a lack of supplies.

By June 7, all five beaches were securely in control of the Allied forces although it was only six days later that they were all linked together in a defensive perimeter. Nevertheless, the German Army had not been able to prevent the landings and, as the Allied forces continued to multiply, Rommel's prediction that Germany's only chance was to regain control of the beaches within the first twenty-four hours became an unquestionable reality. The landings which had for so long been dreaded by the Allied commanders, because they expected intolerably high casualties, were over and had laid the foundation for liberation of Western Europe bringing in the end of the war in sight for the first time. The Allied forces lost over 10 000 men on D-Day but many more were to die in the days that followed and the city of Caen finally fell to the Canadians on 18 July.

The Union Defence Forces (UDF) of South Africa were not present as an operational entity in Normandy on D-Day. The UDF was otherwise occupied at that time with operations in the Central Mediterranean Theatre (CMF) where 6 SA Armoured Division was busily chasing Field Marshall Kesselring's mountain divisions up through Italy and doing it well enough to provide Overlord's planners with a much needed second front. The fact that Rome was liberated on 4 June 1944, is often overlooked due to the momentous events which followed on the French coast less than 24 hours later. This was the first European capital to fall, and a victory in which the South Africans had played a major role.

Nevertheless it should not be forgotten that during World War Two approximately 3000 South Africans were seconded to the British armed forces thereby affording the Union representation in all the battle theatres. Of these an estimated 900 South Africans and Britons who later immigrated to South Africa, actually took part in the D-Day Landings in Normandy on 6 June. UDF personnel had been seconded to the Royal Navy, Royal Air Force, Royal Marines and the British Army but were still easily distinguishable from their British counterparts by the orange shoulder flashes which they wore. The rest of the South African contingent were men and women who had volunteered directly for service in the British Armed Forces at the start of the war.

Of the seconded South African personnel the largest group present on D-Day were men serving with the Royal Marines and the Royal Navy. Approximately 75 men were serving as officers with the Royal Marines to which they had been seconded on 27 December 1943 while doing duty in Alexandria. These officers were posted to 48 and 45 Commandos, the Parachute Regiment and the Small Craft Squadron. Regarding the Union's volunteers seconded to the British Army, most of them could be found serving in the Royal artillery, armoured and infantry corps whilst the bulk of the female volunteers were serving in the Royal Army Medical Corps. Almost all of these personnel held officers' ranks, this was primarily due to the fact that the UDF had a surplus of officers whom the British commanders were quite happy to accommodate as UDF officers were generally rated as being of a very good standard (by Field Marshall Montgomery in particular).

The army officers were therefore dispersed amongst various British Army formations on DDay where many of them served with distinction. One group of soldiers deserve a special mention, that being the group of 22 men who were attached to the British parachute regiment. Originally these chaps had all been members of the SAAF Regiment's parachute Squadron which was established at the end of the hostilities in the Western Desert and carried out its training courses at Premier Mines. 

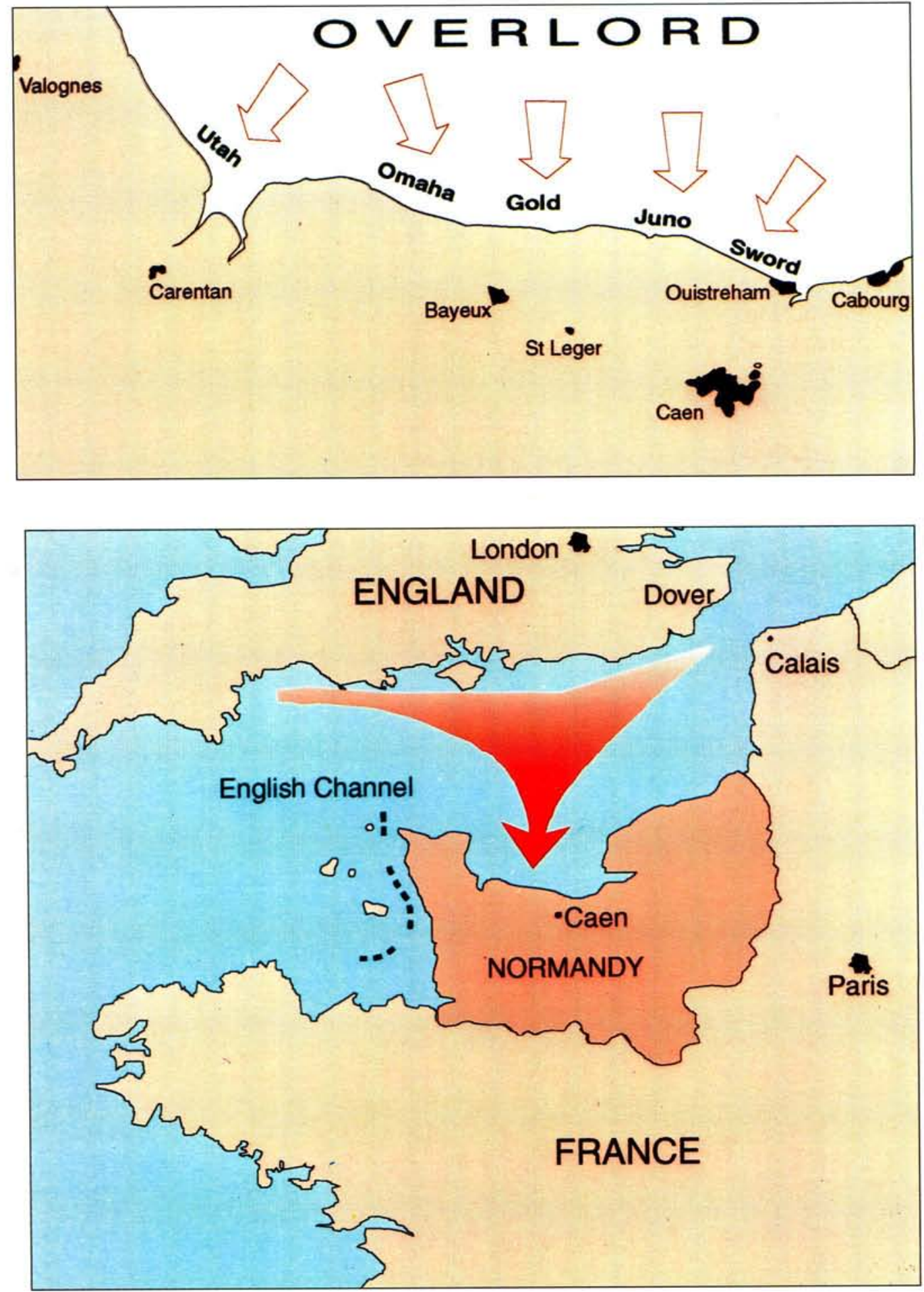

Unfortunately the unit was disbanded and its members absorbed in the Natal Mounted Rifles for duty in Italy. It was at this point that the above mentioned group of soldiers joined the British Army. They parachuted into Vichy France near Cannes in a manoeuvre known as Operation Anvil in order to prevent German reinforcements from getting down the coast to face the main Allied invasion force and the operation was to all intents and purposes very successful.
Whilst on the subject of air operations albeit of a different kind, it is widely recognised that some of South Africa's most outstanding war personalties could be found in the Royal Air Force, the large number of Union pilots in the RAF had established an enviable reputation, not only inside flying circles but amongst the British public as well. Of these the most famous would probably be Group Captain Adolf "Sailor" Malan who had revitalised RAF fighter tactics so successfully during the Battle of Brit- 
ain. "Sailor" trained the RAF No. 20 Fighter Wing for the invasion of France and on D-Day accompanied his squadrons on a number of sorties over the Normandy beaches. Later in the day he agreed to perform the special task of escorting the troop-carrying aircraft and glider planes which were operating on throughout the night. "Sailor's" contribution to the Royal Air Force on this day and throughout the war was immeasurable. Another South African hero who flew in Operation Overlord was Squadron Leader J.J. le Roux who became the highest scoring fighter pilot in Normandy from the time of the D-Day invasions. Le Roux was able to achieve what an entire squadron of SAS operators dropped behind German lines had been unable to - that being to assassinate or capture Rommel. It was due to him that Erwin Rommel was relieved of his command on 17 July. Rommel's car was bombed by the South African fighter ace, and the wounds he sustained were so serious that it was believed he would never properly recover. The "Desert Fox" was consequently declared unfit for further duty and relieved of his command on 17 July.

Two other South Africans who were not part of the invasion force but nevertheless deserve a special mention for their role in the Allied victory on D-Day. One of them was the SA Army officer, Major A.S. du Toit who played an invaluable but little known role in the Allies armoured successes. Most of the obstacles installed on the Normandy beaches by the Germans would have wrecked the Allied tanks, a particular threat in this area being mines. This problem was overcome by Maj du Toit who devised a "Flail Tank". This entailed a rotating drum which was carried on arms ahead of the tank hull and driven by means of a shaft from the truck engine mounted on the tank hull. Chains were attached loosely to the drum so that as it revolved, the free ends of the chains flailed the ground beneath, ahead of the advancing tank with sufficient force to detonate any mines. This became known as the Sherman "Crab" and played a large role in ensuring that the Allied armour played a vital and effective part in the invasion.

The second mention must go to Field Marshall Jan Smuts who, as a close colleague of Bernard Montgomery, played an important advisory role in the drawing up of the British assault plan. At the final senior briefing on Overlord held on 15 May a unique assembly of Allied commanders was gathered to present their invasion plan to King George VI, Winston Churchill and Jan Smuts, who proved to be instrumental in helping to streamline and con- solidate the Allied plan. It is a credit to Smuts that he is the only non-Briton ever to have sat in a British war cabinet. In fact, he was held in such high esteem by the King, Churchill and the British commanders that if Winston Churchill had died or fallen ill during the latter years of the war, Smuts would have become Britain's acting Prime Minister. It is thus fitting that, even though, the South African contingent on D-Day was small we can be rightly proud of the Union's contribution which took root in the highest echelons and was later represented in every single arm of the British fighting services.

\section{SELECT BIBLIOGRAPHY}

\section{Archival Sources :}

Union War Histories Group (UWH), Box 345, The Campaign in North Western Europe.

UWH, Box 310, The D-Day Landings.

UWH, Box 293, South African Volunteers in the British Forces.

\section{Books :}

Brown., A. (ed): The SAS - Elite Forces. Orbis Publications, London, 1986.

Cryws-Williams., J.: A Country at War. Ashanti Publishers, Rivonia, 1993.

Gilbert., M.: Second World War. George, Wiedenfeld and Nicolson, London, 1989.

Goralski., R.: World War Two Almanac 1931-1945; A political and military record. Hamish Hamilton, London, 1981.

Harris., C.J.: War at Sea. Ashanti Publishing, Rivonia, 1992.

Hogg., I.: Great Land Battles of World War Two. Blandford Press, United Kingdom, 1987.

Hughes., G. (ed): The World at War, 1939-1945; An illustrated history of the Second World War. Color Library Books, New York, 1991.

MacDonald., C.: By Air to Battle; Purnell's History of the Second World War. MacDonald and Co, London, 1970.

Natkiel., R.: Atlas of 20th Century Warfare. Bison Books, London, 1986.

Rutherford., W.: -The Biography of Field Marshall Erwin Rommel. Hamlyn, London, 1981.

Somerville., D.: Monty; A Biography of Field Marshall Montgomery. The Bison Group, London, 1992.

Walker., O.: Sailor Malan; A Biography. Cassel and Co, London, 1953. 